Pliocene in Western Australia ${ }^{10}$, so the open scrub heath can be assumed to have been present at this time, while local survival of the rain forest continued in the north-east ${ }^{11}$. Undoubtedly the heathland has been further favoured in the late Quaternary by the arrival of man and an associated increase in the frequency of fire.

There is, therefore, a considerable difference in age between the Australian and the northern European heathlands. Although there are records of heathland pollen assemblages from pre-glacial Pleistocene sediments in Britain ${ }^{12}$, such ecosystems have subsequently been regularly disturbed by glacial episodes. In Australia, the Pliocene heaths appear to have had a long period in which to evolve without interruption by such extreme factors as glaciation. This may account for some of the observed differences between Northern and Southern Hemisphere heaths in terms of the evolution of seed strategies. Convergent evolution might well continue, were ours given sufficient time to catch up.

Peter D. Moore is at the Department of Plant Sclences, University of London King's College, 68 Half Moon Lane, London SE24 9JF.

\title{
Cell signalling
}

\section{Dual control of adenylate cyclase}

\section{from Miles Houslay}

MANY hormones exert their effects on target cells by elevating the intracellular concentration of cyclic AMP, which acts as a 'second messenger'. They achieve this by binding to specific receptors on the cell surface, which then activate the enzyme adenylate cyclase. The interaction between these two entities is mediated by a distinct regulatory protein $\left(\mathrm{N}_{\mathrm{s}}\right)$ which is dependent on guanine nucleotides for function. Recently, excitement has focused on observations that certain receptors, for example muscarinic, opiate and $\alpha$-adrenoceptors, actually lead to inhibition of adenylate cyclase activity. Indeed, it would seem that in many cells, adenylate cyclase is under dual control. Furthermore, guanine nucleotides are essential for the expression of these inhibitory effects. This has raised the question of whether a single guanine nucleotide regulatory protein mediates both stimulatory and inhibitory effects, or whether distinct regulatory proteins exist. Very recent observations from several laboratories ${ }^{1-6}$ have suggested that the latter alternative is correct. In this edition of Nature ${ }^{7}$, Jakobs and co-workers demonstrate that a fully functional hormone- and guanine-nucleotidecontrolled inhibitory response is displayed by a somatic cell variant (cyc) which is genetically deficient in the stimulatory guanine nucleotide regulatory protein, $\mathrm{N}_{\mathrm{s}}$.

The S49 mouse lymphoma cell line has proved, yet again, to be a powerful tool for identifying the molecular components of the adenylate cyclase system. This cell possesses a $\beta$-adrenoceptor that stimulates adenylate cyclase activity in the presence of $\beta$-agonists. However, high concentrations of cyclic AMP are toxic to the cells, enabling mutants defective in cyclic AMP metabolism to be selected. One such mutant, $c y c^{-}$, has proved invaluable ${ }^{8}$. Although it possesses a $\beta$-adrenoceptor and catalytic unit of adenylate cyclase, $\beta$ agonists do not stimulate cyclic AMP production, and guanine nucleotides, sodium fluoride and cholera toxin also fail to stimulate the enzyme. Indeed, the activity of adenylate cyclase is so low that originally cyc was thought to be deficient in this enzyme. Later studies showed, however, that it could be exposed if $\mathrm{Mn}^{2+}$ rather than $\mathrm{Mg}^{2+}$ was used as co-substrate and in a key experiment, Ross and Gilman ${ }^{9}$ demonstrated that both hormone- and guanine-nucleotide-stimulated activities could be reconstituted in $\mathrm{cyc}^{-}$membranes using a detergent extract from the plasma membranes of wild-type cells whose adenylate cyclase had been heatinactivated. This led to the suggestion that what was missing from cyc cells was a distinct guanine nucleotide regulatory protein, $\mathrm{N}_{s}$; and this protein has since been purified to homogeneity from rabbit liver ${ }^{10}$.

The same $c y c^{-}$variant has now been used by groups in Créteil, Houston and Heidelberg ${ }^{5,11}$ to identify a distinct $\left(\mathrm{N}_{\mathrm{i}}\right)$ guanine nucleotide regulatory protein that mediates inhibitory responses. To detect inhibition of the adenylate cyclase in $\mathrm{cyc}^{-}$ membranes it was necessary first to amplify the residual activity of the enzyme. $\mathrm{Mn}^{2+}$ could not be used as it not only perturbs guanine nucleotide responses but it also 'uncouples' both stimulatory and inhibitory effects. The trick proved to be the use of forskolin, a diterpene which can act as an extremely powerful activator of adenylate cyclase ${ }^{12}$, which made it possible to show that the adenylate cyclase activity of $c y c^{-}$cells was indeed inhibited by guanine nucleotides. Such inhibition was elicited using much lower concentrations of non-hydrolysable analogue sof GTP than with GTP itself, whereas the opposite is true for stimulatory responses. With Jakobs and co-workers' observation ${ }^{7}$ that somatostation produces a guanine nucleotide-dependent inhibition of adenylate cyclase here, it seems that a complete hormone-controlled inhibitory system exists in cyc $^{-}$cells.

The nature and mechanism of action of this inhibitory regulatory protein now re- quires elucidation. A useful tool may prove to be islet-activating protein (IAP) from Bordatella pertussis. IAP blocks the effect of inhibitory hormones on adenylate cyclase, apparently through the ADP ribosylation of a distinct membrane protein ${ }^{13}$. This target protein has a molecular weight of $39-41,000$ and is not a substrate for cholera toxin, which specifically ribosylates subunits of molecular weight 52,000 and 45,000 forming part of $N_{\mathrm{s}}$. The IAP target protein has been purified and seems to be a heterodimer consisting of both 41,000 - and 35,000-molecular weight polypeptides ${ }^{14}$. It has strikingly similar physical properties to $N_{s}$ and may well turn out to be $\mathrm{N}_{\mathrm{i}}$ itself. Indeed, Birnbaumer and co-workers ${ }^{6}$ have very recently demonstrated a 39,000-molecular-weight substrate for IAP in membranes from $c y c$ cells. Moreover, treatment with IAP renders the forskolin-stimulated adenylate cyclase insensitive to inhibition by GTP. However, IAP does not block the inhibitory effects of a non-hydrolysable analogue of GTP on $c y c^{-}$adenylate cyclase, which suggests that the system has a considerable complexity. As to mechanism, it has been suggested that the regulatory proteins are both GTPases with the GTP form being the active state; this suggestion has however been criticized, not least because purified functional $\mathrm{N}_{\mathrm{s}}$ does not exhibit GTPase activity.

Whether further distinct guanine nucleotide proteins linked to specific receptors will be discovered, as Rodbell ${ }^{15}$ has suggested, remains to be seen. Indeed, in this light there is the recent provocative suggestion $^{16,17}$ that the insulin receptor, whose mechanism has defied comprehension for many years, may exert some of its effects through interaction with a specific guanine nucleotide regulatory protein with properties somewhat similar to those of $\mathrm{N}_{\mathrm{i}}$.

Miles D. Houslay is Reader in Biochemistry at the University of Manchester Institute of Science and Technology, Manchester M60 $I Q D$.

1. Stiles, G.L. \& Lefkowitz, R.J. J. biol. Chem, 257. 6287 (1982).

2. Insel, P.A., Stengel, D., Ferry, N. \& Hanoune, J. J. biol. Chem. 256, 7485 (1982)

3. Motulksy, H.J. et al. Proc natn. Acad. Sci. U.S.A. 79. 4193, (1982)

4. Scamon, K.B. \& Daly, J.W. J. biol. Chem. 257, 11591 (1982).

. Hildebrandi, J.D., Hanoune, J. \& Birnbaumer, I. J. biol. Chem. 257, 14723 (1982).

6. Hildcbrandt, J.D. et al. Nature 302, 706, (1983).

Jakobs, K.H., Aktories, K. \& Shultz, Ci. Nature 303, 177 (1983).

8. Bourne, H.R., Coffino, P. \& Tomkins, G. Science 187, 750 (1975).

9. Ross, E.M. \& Gilman, A.G. Proc, natn. Acad. Sci. U.S.A. 74, 3715 (1977)

10. Sternwciss, P.C., Northup, J.K., Smigcl, M.D. \& Gilman A.G. J. biol. Chem. 256, 11517 (1981).

11. Jakobs, K.H., Gchring, U., Gaugier, T., Pfeuffer, T. \& Schultz G. Eur. J. Biochem. (in the press).

12. Scamon, K.B. \& Daly, J.W. Trends phamac. Sci. 4, 120 (1983)

13. Katada, T. \& Ui, M. J. biol. Chem. 257, 7210 (1982)

4. Bokoch, G.M., Katada, T., Northup, J.K., Hewlet, E.L.. \& Gilman, A.G. J. biol. Chem. 258, 2072 (1983).

15. Rodbell, M. Nature 284, 17 (1980)

16. Heyworth, C.M., Rawal, S. \& Houslay, M.D. FEBS Lett. 154, 87 (1983).

17. Heyworth, C.M., Wallace, A.V. \& Houslay, M.D Biochem. J. (in the press). 